\title{
The South West Division Prize
}

This prize will be awarded annually and will be open to all trainees in the South Western Division of the College. The object of the competition will be to encourage trainees to undertake research or original work. Initially the prize will be $£ 100$ but this sum will be reviewed by the Executive Committee of the Division from time to time. In addition, the prizewinner will be encouraged to present his or her paper at the
South Western Division Spring Meeting immediately following the announcement of the winner. A detailed list of regulations is available from the Secretary of the Division: Dr Richard Williams, Consultant Child and Adolescent Psychiatrist, Department of Family Psychiatry, Bristol Royal Hospital for Sick Children, St Michael's Hill, Bristol BS2 8BJ.

\section{North West Division}

\section{Cheadle Royal Hospital Prize}

An Annual Prize of $£ 500$ will be awarded for research at consultant level. The competition is open to all consultant psychiatrists in the North West Division of the College, excluding full-time senior academic staff. Material published in the previous year may be included, as may previously submitted research for a higher qualification, provided a substantial amount of the work has been done while in a consultant post.
The adjudicators will comprise the Professors currently Heads of Department at Liverpool and Manchester Universities, together with the Medical Superintendent of Cheadle Royal Hospital.

Further information can be obtained from the Chairman of the North West Division of the College, to whom entries should be submitted by 31 March 1989.

\section{Joint Meeting}

There will be a joint meeting between the Child and Adolescent Psychiatry Specialist Section and the Forensic Psychiatry Specialist Section on 10 November 1988 at the Royal College of Physicians. The probable title of the meeting will be 'Child
Sexual Abuse after Cleveland'. Registration fee will be $£ 20$, to include refreshments. Notification of the meeting will be circulated to both Sections; those from other disciplines are welcome to attend.

\section{Regional Meeting in the Middle East}

There will be a Regional Meeting of the Royal College of Psychiatrists in Cairo from 10-12 March 1989, organised by Dr N. Loza, Director, Behman
Hospital, Cairo. Interested members should contact Miss S. Goodwyn, Overseas Desk, at the College for further information.

\section{Correction}

\section{Distinction Awards in Psychiatry (England and Wales)}

\section{Regional 'C' Awards Committee 1988}

North Western: We have been informed that $\mathrm{Dr}$ A. A. Campbell has been a member of this Committee since 1987 and completes his three year term in
1989. Dr M. D. Cashman has now completed his term but Dr Theodossiadis will be on the Committee until 1990. (see Bulletin, August 1988, 12, 342) 